\title{
Immunoaffinity Chromatography: A Review
}

\author{
Daad A. Abi-Ghanem and Luc R. Berghman \\ Texas A\&M University \\ USA
}

\section{Introduction}

Affinity chromatography is a high resolution, high capacity, and one of the most powerful and diverse methods for separating proteins and other biological molecules of interest on the basis of a highly specific, reversible biological interaction between two molecules: an affinity ligand attached to a solid matrix to create a stationary phase, and a target molecule in a mobile phase. Specifically, immunoaffinity chromatography (IAC) relies on a solid stationary phase consisting of an antibody coupled to a chromatographic matrix or to magnetic beads, and harnesses the selective and strong binding of antibodies to their targets (Hage, 1998). Accordingly, any molecule that can be bound effectively by an antibody can be purified using IAC (Lesney, 2003). Purified antibodies are coupled to the inert solid phase and mixed with the antigen solution under conditions that favor adsorption. Following antigen capture, unwanted antigens are removed by washing, and the purified antigen is released by switching to conditions that favor desorption. Purification (often greater than 1000-fold) and simultaneous concentration of the target protein are thus achieved (Fitzgerald et al., 2011). One of the first uses of IAC was reported in 1951 by Campbell et al. who used immobilized bovine serum albumin on $p$-aminobenzyl cellulose to purify antialbumin antibodies. Since then, there has been a great expansion in the applications of IAC for analytical, clinical, and diagnostic purposes.

\section{Basic components}

\subsection{Antibodies}

\subsubsection{Antibody structure}

The typical Y-shaped structure of an IgG molecule consists of two identical heavy $(\mathrm{H})$ and two identical light (L) chains (50 and $25 \mathrm{kDa}$ each, respectively), linked by disulfide bonds (Fig.1). All four chains consist of constant (C) and variable (V) domains. The lower part of the molecule, called the Fc region, is highly conserved between antibody classes, and mediates effector functions of antibodies. The upper arms of the antibody are referred to as the Fab regions. The $\mathrm{V}$ regions of both heavy and light chains combine to form two identical antigen binding sites. Within each $\mathrm{V}$ domain, amino acid sequence variation, and hence antigen recognition, is predominantly focused around three "hypervariable" regions. These residues are referred to as "complementarity determining regions" (CDRs). CDRs from the variable heavy and variable light chain domains are juxtaposed to create the antigen binding site that recognizes the antigenic epitope, a specific location on the antigen (Elgert, 1996). 


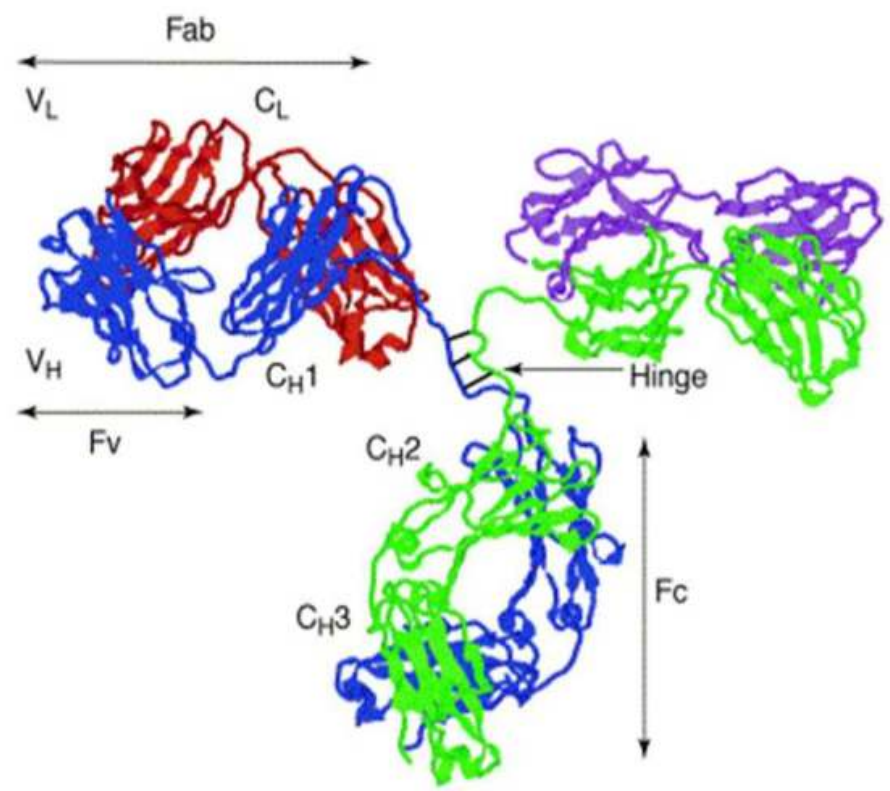

Fig. 1. Structure of an IgG molecule (Modified from Little et al., 2000).

Immunoaffinity chromatography relies on the exquisite binding between an antibody and an antigen, the result of four different types of non-covalent (and therefore reversible) interactions: ionic interactions, hydrogen bonds, van der Waals interactions, and hydrophobic interactions (Harlow and Lane, 1999b; Fitzgerald et al., 2011). Our ability to manipulate antibodies and antibody-antigen interactions offers great potential for the use of IAC in research as well as for therapeutic and diagnostic applications. Moreover, the advent of recombinant antibody production has paved the way for even more advances in manipulating antibodies to our advantage.

\subsubsection{Choice of antibody}

The primary isolation of specific antibodies is necessary for the subsequent purification of specific antigens. Antibodies used as ligands can be purified by precipitation with dextran or ammonium sulfate, or by isolation on a Protein A, Protein G, or Protein L column. The ideal antibody for use in immunoaffinity chromatography should possess two properties: (a) High intrinsic affinity, since an antibody attached to a solid phase has no room for cooperative binding. This is especially important when using a diluted antigen source, where quantitative antigen capture is hard to achieve. Quantitative binding of antigen to the immunoadsorbent along with a low background (non-specific interactions) are insured when using an antibody with an affinity $\geq 10^{8}$ and two hours of antigen-antibody contact. When the antibody affinity is $\leq 10^{6}$, some antigen will be left in solution, and exposure to the antibody column will have to be repeated; and (b) Ease of elution: This depends on the type and number of antigen-antibody bonds: the fewer types of interactions involved, the easier all of them can be destabilized (Harlow and Lane, 1999c). 
Polyclonal antibodies (Pabs) are produced by multiple B-cell clones, and as a population can recognize and bind with varying affinities to a variety of independent epitopes on a single antigen (Fig.2) (Michnick and Sidhu, 2008). In a typical antiserum, only 5\% of the Pabs are target-specific (Harlow and Lane, 1999a). The presence of several antibodies directed at different epitopes of the same antigen makes elution difficult and may damage the chromatography column and denature the antigen.

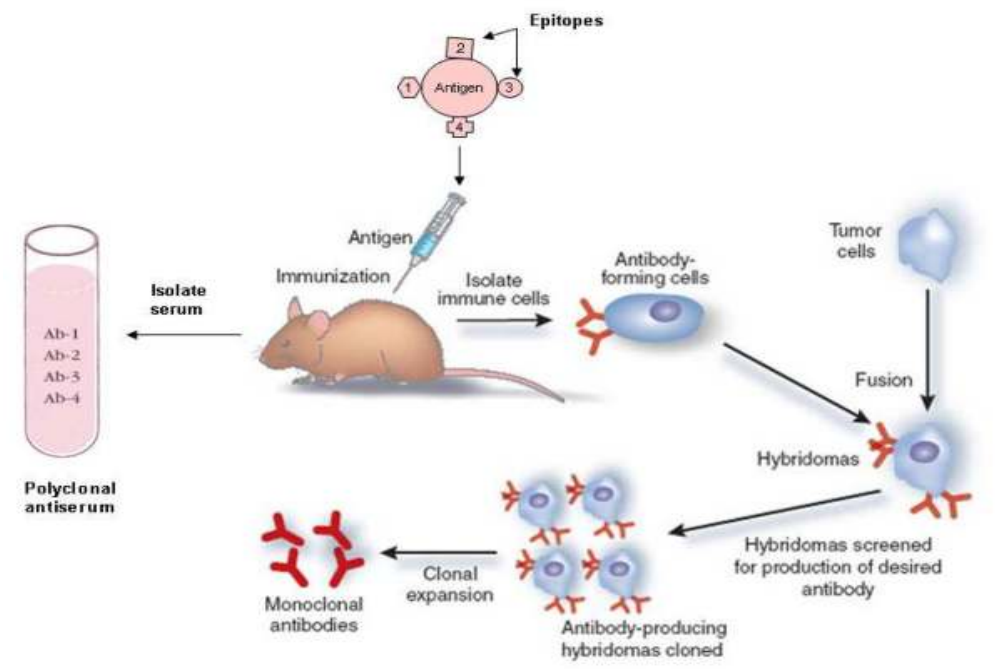

Fig. 2. Overview of poly- and monoclonal antibody production (Modified from Michnick and Sidhu, 2008, and Kuby, 1992)

Pabs are commonly obtained from sera of immunized animals, and are thus available in limited supply; even when a Pab proves suitable for use in affinity chromatography, it is often difficult to obtain multiple lots with consistent quality. To avoid these problems, Pabs can be purified by affinity chromatography over a column of antigen to obtain antigenspecific antibodies, as well as the elution profile of the antigen-antibody interaction, the same conditions of which can then be used to purify the antigen from a crude source. This is seldom practically achievable because it assumes that antigen is available for the purification of antibodies, which are then used to purify the antigen. This may seem like a "Catch-22", but this technology is often used when the host is immunized against a synthetic peptide (conjugated with a carrier protein) that mimics a B-cell epitope on a larger protein. In such a case, the peptide is commercially available in milligram quantities and will allow the isolation of an antigen-specific antibody population that can be used for IAC.

Monospecific Polyclonal Antibodies can alternatively be generated using recombinantly produced (typically) human protein fragments known as protein epitope signature tags (PrESTs). PrESTs are 100-150 amino acid fragments that are selected based on their relative low homology to other proteins in the human proteome (Agaton et al., 2004), thus minimizing cross-reactivity by the generated antibodies (Lindskog et al., 2005). The size of PrESTs is selected to be small enough for easy PCR handling and cloning, and large enough 
to provide conformational epitopes. PrEST selection also avoids certain restriction enzyme sites, transmembrane regions (which are poorly expressed in Escherichia coli), and signal peptides that are cleaved off during translocation in E. coli (Lindskog et al., 2005). PrESTs are expressed as fusion proteins to an albumin-binding protein and to a His 6 tag. The former functions as a "carrier protein" and confers an increased immune response (Libon et al., 1999), while the latter facilitates purification under denaturing conditions from E. coli inclusion bodies (Crowe et al., 1994). Following PrEST selection, expression, and purification, mass spectrometry and SDS-PAGE analysis are used to verify sequence accuracy and to provide protein purity analysis, respectively. The bicinchoninic acid assay is then used for determination of protein concentration of the purified PrEST antigens (Gunneras et al., 2008). PrEST-specific polyclonal antibodies are then obtained by immunizing animals with the purified PrEST proteins, and are in turn purified by using the PrEST proteins as affinity chromatography ligands. PrEST-specific polyclonal antibodies are extremely useful for expression and localization studies in both normal and diseased tissue using tissue microarrays (Larsson et al., 2006; Kampf et al., 2004).

A monoclonal antibody (Mab) is the product of a single immortal hybridoma cell line (a clone), and is thus available in unlimited supply. Mabs possess exquisite, well-defined specificity to a single epitope, and constitute a homogeneous binder population (Fig.2). High-affinity Mabs can bind to a large proportion of antigen. All antibodies bind to the same epitope, making elution conditions easy and gentle. The use of a pool of different Mabs is not recommended, as different epitopes on the antigen will be recognized, making desorption difficult and hence possibly denaturing the antigen and damaging the antibody column (Harlow and Lane, 1999c). Note that it is not necessary to have pure antigen to produce a monospecific Mab (Gustafsson, 1990). Therefore, a seemingly paradoxical approach becomes feasible: first making the specific Mab and then using it to isolate the corresponding antigen from the immunogen mix afterwards.

Recombinant antibodies and antibody fragments are produced in vitro by antibody phage display, bypassing the need to immortalize immune B-cells, as antibody genes are immortalized instead (Winter and Milstein, 1991). Antibodies can be produced as Fab, $\mathrm{F}\left(\mathrm{ab}^{\prime}\right)_{2}$ (two Fab units and the hinge region), single-chain antibody fragments (scFv), and diabodies (a dimeric scFv) (Rader and Barbas, 1997) (Fig.3). An scFv fragment is the smallest Ig fragment (one-sixth of a complete $\mathrm{Ab}$ ) containing the whole antigen-binding site (Yokota et al., 1992). Following the cloning of the genes encoding the antibody heavy and light gene fragments, a large antibody repertoire can be constructed. Because heavy and light chains are combined randomly, each phage has the potential to display on its surface a unique antibody with a specific antigen-binding site (Rader and Barbas, 1997; Pini and Bracci, 2000). The genetic information encoding the displayed molecule is contained within the phage coat, thus providing a direct physical link between genotype and phenotype (Rader and Barbas, 1997). This linkage endows the protein with the two key characteristics of molecular evolution: replicability and mutability (Smith and Petrenko, 1997): It allows the selection, amplification, and manipulation of a specific clone from pools of millions. Moreover, the amino acid sequence of a selected phage can be deduced by deciphering the DNA sequence within (Barbas and Wagner, 1995). Because of the direct physical linkage between the DNA genotype and the antibody phenotype, recombinant antibodies are also easily optimized, and are amenable to fusions with proteins and peptides (drugs, toxins...) (Little et al., 2000; 
Azzazy and Highsmith, 2002). Peptide tags can easily be introduced into recombinant antibodies, greatly facilitating purification and detection (Andris-Widhopf et al., 2000). Using phage display, antibodies can be expressed in E. coli, yeast, plants (plantibodies) against virtually any antigen, including conserved antigens, non-immunogenic molecules, and toxic molecules (Little et al., 2000; Hoogenboom and Chames, 2000). In addition, recombinant human or humanized antibodies circumvent the human response elicited by murine mAbs (Maynard and Georgiou, 2000). Regarding IAC, recombinant antibodies have the same advantages as monoclonal antibodies, i.e. monospecificity against a single epitope.

\section{scFv}

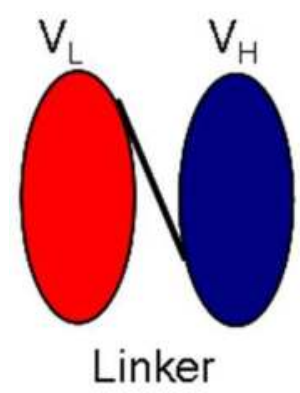

Fab

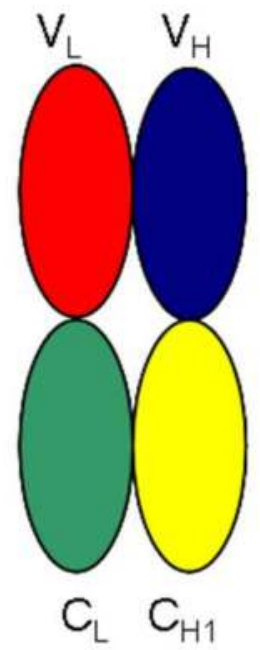

Diabody

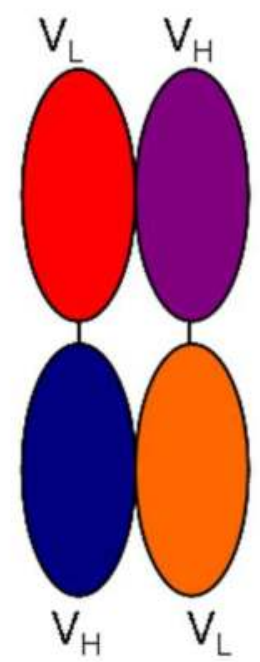

Fig. 3. Structure of scFv, Fab, and diabody antibody fragments.

The use of avian antibodies, IgY, has several major advantages. Chickens are phylogenetically very distant from mammals, and hence can be used to produce antibodies against highly conserved or weakly immunogenic mammalian epitopes (Jensenius et al., 1981). Avian antibodies are most commonly produced in eggs. Because chickens are inexpensive to maintain and a high yield of antibody can be obtained from the eggs, they represent a relatively inexpensive source of antibodies (Berghman et al., 2005). Eggs are more easily collected than blood samples, and a few eggs per week can provide the same amount of immunoglobulin as repeated bleeding of an immunized rabbit (Chui et al., 2004). However, for IAC, avian antibodies have the same drawbacks as mentioned above for Pabs, in that they represent a mix of specificities and affinities, unless they can be first purified against the antigen.

\subsection{Solid matrix}

The immunoaffinity matrix onto which the antibody ligand will be attached should be inexpensive, readily available, easy to use, and highly stable: the support material and the attached ligand should not react with the solvents used in the purification process, and 
should be resistant to degradation or damage by enzymes and microbes that might be present in the sample. It should also be able to withstand physical stress (i.e. pressure), especially when packed into a column, should remain intact throughout the purification process, and be easily regenerated under relatively harsh conditions (Urh et al., 2009). The IAC matrix should be easily modified for antibody attachment, and should be macroporous with uniform particle and pore size and good flow properties (Urh et al., 2009). A compromise should be achieved between pore size and surface area, as supports with small pore size have a large surface area, much of which may not be available for immobilization of antibody (Gustavsson and Larsson, 2006). In contrast, large pore support systems do not have accessibility problems, but may result in a low level of antibody attachment due to the small surface area. Supports with pore sizes of $300-500 \AA$, which is approximately three to five times the diameter of an antibody, allow for maximum antibody coverage, as well as for suitable binding of immobilized antibodies to many small or medium sized targets (100-150 kDa) (Clarke et al., 2000).

Conventional matrices for use in IAC systems have been based on low-pressure resistance, allowing their operation under gravity flow with a slight vacuum or peristaltic flow applied (Schuste et al., 2000). These matrices include carbohydrate-based media (agarose, dextrose, or cellulose), synthetic organic supports such as acrylamide polymers, polymethacrylate derivatives, polyethersulfone matrices, or inorganic materials such as silica and zirconia (Fitzgerald et al., 2011). Cross-linked agarose is an extremely popular matrix because it can usually withstand a wide $\mathrm{pH}$ range (e.g. $\mathrm{pH}$ 3-12), most aqueous solvents (including denaturants), many organic solvents or modifiers, and enzymatic treatments. However, agarose beads and other soft gel matrices are more susceptible to pressure, relative to stronger supports, such as silica, polystyrene and other highly cross-linked materials (Urh et al., 2009). Immunomagnetic beads represent an example of a solid support with better chemical and hydrodynamic properties than conventional supports. Advantages of magnetic separation include quick retrieval of affinity beads at each step, thereby significantly shortening the purification process; bypassing sample pre-treatment such as filtration or centrifugation; and the ability to use viscous materials that would otherwise clog traditional columns (Urh et al., 2009). Magnetic particles are also available conjugated with common affinity ligands (Protein A, Protein G, streptavidin), or with specific monoand polyclonal antibodies (Koneracka et al., 2006).

\subsection{Antibody immobilization methods}

The key factor in antibody immobilization onto the affinity matrix is to tightly bind the antibody to the support medium without interfering with the activity and accessibility of the antigen binding site (Kim and Hage, 2006). There are two fundamentally different ways of immobilizing antibodies to a support:

\subsubsection{Random chemical attachment}

This easy method usually targets the Lysine $\varepsilon$ - amino groups on the antibodies. However, a decrease in activity is observed if the antibodies have some of those amine groups in their binding sites (Kortt et al., 1997). Steric hindrance and a decrease in binding efficiency may also occur, because the antibodies are immobilized in a random orientation, which bears the risk of having the binding site blocked by the attachment (Turková, 1999). 
Covalent linkage of antibodies to the reactive groups of activated, commercially available beads is a cheap, fast, and robust method of antibody attachment to the solid phase. A typical example is cyanogen bromide $(\mathrm{CNBr})$-activated Sepharose (Nisnevitch and Firer, 2001), but various alternatives are available [tosyl and epoxy activated beads] (Hage, 1998; Larsson, 1984). This simple, straightforward methodology is recommended when the amount of antibody available is not expected to be a limiting factor, e.g. when the researcher has access to a hybridoma that can theoretically produce unlimited amounts of antibody. As pointed out above, the antigen-binding capacity of the antibody can be lost in the process of covalent bonding to the support; statistically this happens in two out of three attachments, and only one out of three antibodies is optimally immobilized, maintaining the potential binding of two antigen molecules. Nevertheless, the remaining capacity can still be impressive compared to the concentration of the target molecule in the extract to be purified. For instance, if $1 \mathrm{ml}$ of CNBr-activated Sepharose slurry is derivatized with $5 \mathrm{mg}$ of antibody (a typical ratio) and if one in three antibodies remains fully active (and can thus bind two antigen molecules), its binding capacity for a $25 \mathrm{kDa}$ molecule is still approximately $500 \mu \mathrm{g}$ per run. Another potential downside of random chemical attachment of antibodies is that the coupling capacity of the beads is so high (up to $30 \mathrm{mg}$ of protein per $\mathrm{ml}$ of CNBr-agarose), that multipoint attachment can occur, which is another mechanism through which antigen-binding capacity can be lost. This can be prevented by limiting the time of the coupling reaction, or by adding some "inert" protein to the antibody to be coupled, so as to create competition for the available binding sites, and thus lower the probability of multipoint attachment.

Antibodies can also be immobilized onto a matrix by using a secondary ligand. In this case, biotinylated antibodies are adsorbed to a support containing immobilized avidin, streptavidin, or neutravidin (Moser and Hage, 2010). However, and unless antibodies are biotinylated at their Fc carbohydrate groups (O'Shannessy and Quarles, 1987), a decrease in binding capacity and efficiency may result from biotin molecules attaching at or near the antigen binding site, and/or from biotinylated antibodies randomly attaching to the streptavidin support (Moser and Hage, 2010).

\subsubsection{Directional attachment}

The most common way to achieve oriented attachment is to covalently stabilize the (reversible) bond between the antibody and Protein A, Protein G, or Protein L beads (Moser and Hage, 2010; Urh et al., 2009). Proteins A and G bind to the Fc portion of the antibody, while Protein L interacts with kappa light chains. None of these proteins blocks the Fab sites. Stabilization of the bond between antibody and binding protein is achieved by incubation with a bifunctional reagent (a cross-linker) of the ideal length. A typical example is dimethyl pimelimidate (Schneider et al., 1982), but alternatives with different lengths are also available. The quality of the immunoadsorbent can easily be checked by saving $50 \mu \mathrm{g}$ of beads before and after the cross-linking reaction. The former should yield a $50 \mathrm{kDa}$ band and a $25 \mathrm{kDa}$ band under reducing SDS-PAGE, while the latter should no longer show the $50 \mathrm{kDa}$ band, since the Fc fragment is supposed to be cross-linked with protein A. In spite of their attractiveness, immunoglobulin-binding beads are expensive, will bind extraneous antibody that might be present in the sample extract, and their specificities are not universal, but rather isotype-dependent. Proteins A and G possess different affinities for IgG types 
from different species, and even for IgG isotypes within the same species. Protein L can only bind certain subtypes of kappa light chains (Urh et al., 2009).

Oriented attachment is also possible via targeting the antibody's carbohydrate or sulfhydryl groups in the Fc fragment. For instance, antibodies can be coupled to the carbohydrate moieties found on the Fc, but not the Fab fragment (Ruhn et al., 1994; Nisnevitch and Firer, 2001). The Fc carbohydrates are first oxidized by incubation with sodium metaperiodate. The aldehyde groups that result from this oxidation are then reacted with a hydrazideactivated matrix (which is commercially available). The alternative is to reduce the disulfide bridge that links the two immunoglobulin heavy chains using a mild reducing agent such as 2-mercaptoethylamine. This leaves the disulfide bridges of the Fabs intact, but results in two "half-antibodies" with exposed sulfhydryl groups. The latter are then reacted with an iodoacetyl- or maleimide-activated matrix to form a chemically stable immunoadsorbent with full antigen-binding capacity (Spitznagel et al., 1993; Mallik et al., 2007).

\section{Sample extraction}

Recombinant protein production permits high-level expression of foreign proteins in hosts such as Escherichia coli, Saccharomyces cerevisiae, and Pichia pastoris. Host cells are then disrupted and the expressed target protein is released. The choice of the method for cell disruption and sample extraction is an empirical process that is highly dependent on the uniqueness of the target protein, the different cell types, and the scale of purification. In any case, such methods should be rapid and efficient while conserving the target protein's conformation and activity by minimizing proteolysis or oxidation, and reducing or preventing unnecessary lysis of the cell nuclei to prevent an increase in viscosity generated by the presence of genomic DNA strands (Grabski, 2009).

\subsection{Preparation of cell lysate}

\subsubsection{Chemical and enzymatic cell disruption}

These methods are particularly suited for small, laboratory-scale protein purification, and employ detergent-based reagents (such as B-PER ${ }^{\circledR}$, Thermo Scientific and BugBuster ${ }^{\circledR}$, EMD Chemicals) for effective cell disruption. These reagents are very fast and easy to use, do not require expensive equipment, and can readily be combined with lytic enzymes and nucleases for more efficient cell lysis and protein extraction from bacteria, yeast, plant cells, insect cells, and higher eukaryotes (Grabski, 2009). Another class of detergent-based reagents (such as B-PER $®$ Direct, Thermo Scientific) allows for high throughput automative processing of samples. Use of these reagents alongside high-activity lysozyme and nuclease permits for cell growth, extraction, and purification to take place in a single test tube or well, bypassing the need to separate the host cells from the culture media. The active ingredients of these reagents are detergents that weaken the host cells for rupture by disrupting cell membrane and cell wall structures. Concurrent treatment with lysozyme further breaks down cell walls, whereas the use of nucleases limits viscosity. Enzymatic treatments are further advantageous because they are gentle, simple, require no specialized instrumentation, and do not generate shear, heat, or oxidative damage. However, the optimal conditions for lytic enzymes ( $\mathrm{pH}$, temperature) may not be compatible with the target protein, and the presence of the enzyme in the extract may interfere with downstream 
purification and processing. The limited availability and cost of lytic enzymes further curbs their use at an industrial scale (Grabski, 2009).

\subsubsection{Mechanical cell disruption}

Mechanical methods of cell disruption are highly effective, rapid, cheap, and thus suited for large scale purification. The most popular mechanical disruption methods include sonication and high pressure homogenization (Harrison, 1991). These are not suitable for small culture volumes $(<5 \mathrm{ml})$ because of inherent excess heat generation and oxidation damage (Grabski, 2009). Glass bead homogenization can be used at both laboratory and industry scale, and is effective for use with bacteria, plant and animal cells, yeast, spores, and fungi. Grinding with glass beads (on a vortex mixer or blender) creates abrasive and shear forces between the cells, the beads, and the reaction chamber itself. Care must be taken, however, to avoid excessive viscosity generated by the release of nucleic acids (Grabski, 2009; Harrison, 1991). Mechanical methods can be combined with an enzymatic method to increase the rate of cell disruption and extraction yield, reduce viscosity, and minimize product damage (Grabski, 2009).

\subsection{Extraction buffer composition and volume}

Besides being critical to effective cell disruption, the extraction buffer greatly affects subsequent purification steps and the protein's stability and recovery. An ideal extraction buffer promotes fast and efficient binding of the analyte to the immobilized antibodies, and will leave proteins in their native conformation (Moser and Hage, 2010; Grabski, 2009). The important criteria to consider are $\mathrm{pH}$, ionic strength, buffer to cell pellet ratio, and the use of additives. To prevent precipitation, the buffer $\mathrm{pH}$ should be one unit above or below the isoelectric point of the target protein. An ionic strength of $20-50 \mathrm{mM}$ and the presence of $50-$ $100 \mathrm{mM}$ sodium chloride will maintain buffering capacity, and will minimize ionic interactions in the cytoplasm that might lead to adsorption of target protein to charged particulates and its subsequent loss upon centrifugation or filtration (Grabski, 2009).

Proteolysis, dephosphorylation, and denaturation of protein occur as soon as the host cells are lysed. These processes can be slowed down dramatically by keeping the samples on ice and adding appropriate enzyme inhibitors to the lysis buffer just before use. For convenience, cocktails of different protease and phosphatase inhibitors (Aprotinin, PMSF, EDTA...) are commercially available. Other additives that can improve stability of the extracted protein include reducing agents to maintain reduced disulfide bonds, detergents to increase solubility of hydrophobic proteins, kosmotropes (such as glycerol, trehalose, and glycerol) to stabilize intermolecular interactions, and nucleases to reduce sample viscosity. However, the potential interference of these additives with downstream purification and detection must be considered and evaluated (Grabski, 2009).

To ensure effective disruption and adequate recovery, the volume of buffer used to resuspend cell pellets should be at least three times the volume of the original pellet. This will ensure at least $85 \%$ recovery of the liquid fraction obtained after removal of insoluble cell debris. A more soluble and less viscous protein extract can be obtained by using 5-10 volumes of extraction buffer, since highly concentrated extracts are susceptible to aggregation and will decrease diffusion rate and capture by the immunoaffinity matrix (Grabski, 2009). 


\subsection{Pre-clearing of lysate}

To remove proteins that bind nonspecifically to the affinity matrix, the extract can be preincubated with the support matrix, or pre-cleared by incubation with an irrelevant antibody of the same species or with normal serum. This pre-clearing step will result in a lower background and an improved signal-to-noise ratio (Harlow and Lane, 1999c).

\subsection{Removal of extraneous matter}

Ahead of purification, particulate matter and contaminants must be removed from the extract by centrifugation and/or filtration, in order to avoid clogging of the chromatographic column. It may also be necessary to perform a desalting and buffer exchange step in order to transfer the sample to the correct buffer conditions ( $\mathrm{pH}$ and salt concentration), and to remove unwanted small molecules. If the sample is reasonably clean after centrifugation, this last step can be omitted and replaced with a mere adjustment of the sample $\mathrm{pH}$ and ionic strength to that of the application buffer (Harlow and Lane, 1999c). Finally, if the sample extract represents a diluted protein solution, concentration of the sample before purification may be necessary to enhance the probability of quantitative recovery of the target molecule.

\section{Sample adsorption}

Because the antibody is bound to a solid phase, adsorption conditions should maximize antigen-antibody interaction (Harlow and Lane, 1999c). The efficiency of binding is related to the strength and the kinetics of this interaction, which in turn depend on the amount of immobilized antibody, the concentration of applied target, and the flow rate used for binding (Grabski, 2009). Binding can be performed in column or batch format (where the sample extract serves to keep the gel beads in suspension). The former allows for adjustment of flow rates, and therefore for extending the time of antigen-antibody interaction. Generally, a higher flow rate will reduce the binding efficiency, especially when the antibody-target interaction is weak, and/or the mass-transfer rate in the column is slow. In batch purification, the resin and sample are constantly mixed, thus promoting a maximum contact between the target and immobilized antibody. It often saves time, especially when dealing with large sample volumes, but requires optimisation of the amount of resin used. Because excess resin can result in an increase in nonspecific binding, as well as reduced target recovery due to readsorption during the elution step, it is preferable to saturate the resin with bound target (Harlow and Lane, 1999c; Grabski, 2009).

Optimal binding between antibodies and their targets typically occurs under physiological conditions, so the application buffer used in IAC is of neutral $\mathrm{pH}$ (7.0-7.4). This promotes fast and efficient binding of the desired analyte to the immobilized antibodies, with equilibrium constants for antibody binding ranging between $10^{6}$ and $10^{12} \mathrm{M}^{-1}$ (Moser and Hage, 2010).

Following binding, protein bound by nonspecific interactions is removed by washing. Increasing salt $(0.1-0.5 \mathrm{M})$ or changing $\mathrm{pH}$ values will reduce ionic interactions, while decreasing salt, altering $\mathrm{pH}$, or adding surfactants (such as Triton X-100) will remove 
proteins bound by nonspecific hydrophobic interactions. Contaminants with weak affinity to the ligand or to the support matrix itself can be removed by application of low amounts of competitive reagents. It is crucial to determine the appropriate flow rate and volume (e.g., 5-10 column bed volumes) of the wash buffer that will maximally remove contaminants while minimizing loss of target (Grabski, 2009; Harlow and Lane, 1999c).

\section{Sample desorption}

Elution of the antigen, often viewed as the most delicate step of an IAC protocol, should ideally be carried out in a way that keeps the antibody on the immunoadsorbent intact and maintains antigen activity (e.g. enzymatic or hormonal activity), if present, while still allowing later regeneration of the column (Firer, 2001). This is especially important if the column is to be used for a large number of samples. The sample can always be desorbed from the antibody because the four forces that stabilize the antigen-antibody complex (ionic, hydrogen bonding, van der Waals interactions, and hydrophobic bonds) are all reversible. Thus, the antigen-antibody complex can be destabilized by counteracting the forces at work in a particular antibody-epitope interaction. Desorption is thus essentially the reverse process of binding, where conditions are optimized to weaken the antibody-target interaction. Unfortunately, there is no way to figure out a priori what will be an effective eluent from a particular immunoadsorbent; this can only be determined empirically. The elution method of choice is often the use of low $\mathrm{pH}$ (2.0-2.5) which disrupts both ionic and hydrogen bonds between antigen and antibody (Narhi et al., 1997). If that procedure is not effective, the next best choice may be to resort to a commercially available eluent such as Gentle Elution Buffer (Thermo Scientific), the composition of which is proprietary and is reported to destabilize the antigen-antibody complex without damaging either partner of the complex. This solution contains very high concentrations of salts and other agents and requires thorough dialysis of the sample prior to downstream processing.

Denaturing agents (8 M urea or $6 \mathrm{M}$ guanidinium hydrochloride) affect elution by promoting protein unfolding, while chaotropic salts ( $3 \mathrm{M}$ sodium thiocyanate, magnesium chloride) disrupt the water molecules around the affinity interaction (Singh et al., 2003). Both methods, however, can disrupt protein structure and damage labile proteins, resulting in very low yields of active, purified protein. They may also decrease the lifetime of the antibody column (Burgess and Thompson, 2002).

The ultimate eluent is probably SDS denaturation of the antibody-antigen complex. While this may seem excessively harsh, it makes the antigen available for SDS-PAGE and ultimately for mass spectrometric analysis and de novo protein sequence determination. It may therefore be worth sacrificing some antibody (and antigen) in a single use procedure, if it allows one, for instance, to determine with certainty the molecule that a new monoclonal antibody recognizes.

Elution can also be performed in a specific way, by using a displacer agent which will compete with the target protein for binding to the immobilized antibody (Fitzgerald et al., 2011). For example, proteins containing a hemagglutinin (HA) tag can be purified on an anti-HA column, and eluted with an excess of HA. While this elution method is advantageous because of its specificity and mild conditions, the dissociation will ultimately 
depend on the affinity of antibody-target interaction. Also, large molar excesses of the competitor are required, elution is slow and results in broad elution peaks (Urh et al., 2009).

Following elution, the column should always be washed with the application buffer to allow for regeneration of the antibodies before another sample application (Urh et al., 2009).

\section{Applications}

Immunoaffinity chromatography is a versatile, powerful purification method based on wellcharacterized antibody-target interactions, making it amenable for use in many applications, including sample cleanup, and clinical and diagnostic assays for drugs, toxins, and biomarkers. The power of IAC can also be harnessed for use in immunoassays, including sandwich, competitive, and non-competitive binding assays. IAC has also been coupled with other methods such as HPLC, gas chromatography, mass spectrometry (MS), and capillary electrophoresis (CE). In the classic IAC on/off mode (where the analyte is bound to the column, impurities are washed away, and the analyte is then eluted off the column), IAC is commonly used for the selective purification of target compounds (proteins, glycoproteins, carbohydrates, lipids, bacteria, viral particles, drugs) from complex samples. (Weller, 2000; Gallant, 2004). Moreover, if a suitable detector (UV/visible absorbance, fluorescence) is placed after the column, direct detection of the analyte will be possible, provided the analyte is present at a relatively high concentration and is eluted in a sharp, well-defined peak that allows a good detection limit (Moser \& Hage, 2010).

IAC methods are extensively used for sample clean-up prior to analysis of foods for mycotoxins, veterinary drug residues, pesticides, and environmental contaminants (Şenyuva \& Gilbert, 2010). Undesirable components are removed from the sample, preceding the analysis by a second analytical method such as HPLC. This method has been used in the analysis of urine, food, water and soil extracts. A related method, immunodepletion, is used in proteomics for highly selective depletion of multiple highabundance proteins, prior to analysis of minor sample components.

In recent years, IAC has been integrated with other analytical methods such as CE and MS. CE immunoassays (where antibodies are immobilized in CE capillaries) are utilized because they are easily automated, require small amounts of sample and reagents and still maintain a good detection limit, and offer relatively fast separation (Moser \& Hage, 2008; Phillips and Wellner, 2007).

\section{Conclusion}

There are various methods of enriching or purifying a protein of interest from a complex mixture of other proteins and components. Immunoaffinity chromatography is the most powerful and versatile of these methods, an advantage bestowed by the specific binding properties between an immobilized antibody and its target. A single pass through an immunoaffinity column can achieve a 1,000- to 10,000-fold purification of a target from a crude mixture. Before planning an immunoaffinity purification procedure, and assuming an appropriate immobilized antibody is available, one needs to consider the following: (1) the sample source, which will dictate the necessary sample extraction conditions and pre- 
treatment; (2) the scale of purification required; (3) the purity required for the final application; and (4) the economic feasibility, including time and expense.

\section{References}

Agaton, C.; Falk, R.; Hoiden Guthenberg, I.; Gostring, L.; Uhlen, M. \& Hober, S. (2004). Selective enrichment of monospecific polyclonal antibodies for antibody-based proteomics efforts. J Chromatogr A Vol.1043, No.1 (July 2004), pp. 33-40, ISSN 00219673.

Andris-Widhopf, J.; Rader, C.; Steinberger, P.; Fuller, R. \& Barbas, C. F., 3 ${ }^{\text {rd }}$ (2000). Methods for the generation of chicken monoclonal antibody fragments by phage display. $J$ Immunol Methods Vol. 242, No.1-2, (August 2000), pp. 159-181, ISSN 0022-1759.

Azzazy, H.M. \& Highsmith, W.E., Jr. (2002). Phage display technology: clinical applications and recent innovations. Clin Biochem Vol..35, No.6, (September 2002), pp. 425-445, ISSN 0009-9120.

Barbas, C.F. $3^{\text {rd }}$ \& Wagner, J. (1995). Synthetic Human Antibodies: Selecting and Evolving Functional Proteins. Methods: A Companion to Methods in Enzymology Vol.8, No.2, (October 1995), pp. 94-103, ISSN 1046-2023.

Berghman, L.R.; Abi-Ghanem, D.; Waghela, S.D. \& Ricke, S.C. (2005). Antibodies: an alternative for antibiotics? Poult Sci Vol. 84, No.4 (April 2004), pp. 660-666, ISSN 0032-5791.

Burgess, R.R. \& Thompson, N.E. (2002). Advances in gentle immunoaffinity chromatography. Curr Opin Biotechnol Vol.13, No.4, (August 2002), pp. 304-30, ISSN 0958-1669.

Campbell, D.H.; Luescher, E. \& Lerman, L. S. (1951). Immunologic Adsorbents: I. Isolation of Antibody by Means of a Cellulose-Protein Antigen. Proc Natl Acad Sci USA Vol.37, No.9 (September 1951), pp. 575-578, ISSN 0027-8424.

Chui, L.W.; King, R.; Chow, E.Y. \& Sim, J. (2004). Immunological response to Mycobacterium avium subsp. paratuberculosis in chickens. Can J Vet Res Vol.38, No.4, pp. 302-308, ISSN 0830-9000.

Clarke, W.; Beckwith, J.D.; Jackson, A.; Reynolds, B.; Karle, E.M. \& Hage, D.S. (2000). Antibody immobilization to high-performance liquid chromatography supports. Characterization of maximum loading capacity for intact immunoglobulin $\mathrm{G}$ and Fab fragments. J Chromatogr A Vol.888, No. 1-2, (August 2000), pp. 13-22, ISSN00219673.

Crowe, J.; Dobeli, H.; Gentz, R.; Hochuli, E.; Stuber, D. \& Henco, K. (1994). 6xHis-Ni-NTA chromatography as a superior technique in recombinant protein expression/purification. Methods Mol Biol Vol.31, pp. 371-387, ISSN 1064-3745.

Elgert, K.D. (1996). Antibody Structure and Function. In: Immunology: Understanding The Immune System, K.D. Elgert, pp. 58-78, Wiley-Liss, ISBN 0-471-11680-7 New York, USA.

Firer, M.A. (2001). Efficient elution of functional proteins in affinity chromatography. J Biochem Biophys Methods Vol.49, No.1-3, (October 2001), pp. 433-442, ISSN 0165$022 X$.

Fitzgerald, J; Leonard P; Darcy, E \& O'Kennedy R. (2011). Immunoaffinity chromatography. Methods Mol Biol. Vol.681, Part1, pp. 35-59, ISSN 1064-3745. 
Gallant, S. R. (2004). Immunoaffinity chromatography of proteins. Methods Mol Biol. Vol.251, pp. 103-110, ISSN 1064-3745.

Grabski, A. C. (2009). Advances in preparation of biological extracts for protein purification. Methods Enzymol. Vol.463, pp. 285-303, ISSN 1557-7988.

Gunneras, S.; Agaton, C.; Djerbi, S. \& Hansson, M. (2008). Prestige Antibodies--monospecific antibodies designed for immunohistochemical analysis. Biotechniques Vol.44, No.6 (May 2008), pp. 825-828, ISSN 0736-6205.

Gustafsson, B. (1990). Fusion Protocol for the Production of Mouse Hybridomas. In: Methods in Molecular Biology, Vol. 5: Animal Cell Culture, J.W. Pollard \& J.M. Walker (Eds.), pp. 601-607, Humana Press, ISBN 0-8960-3150-0, New Jersey, USA.

Gustavsson, P-E. \& Larsson, P-O. (2006). Support materials for affinity chromatography. In: Handbook of Affinity Chromatography, Hage, D.S. (Ed.). pp. 15-34, Taylor \& Francis, ISBN 978-0-8247-4057-3, New York, USA.

Hage, D.S. (1998). Survey of recent advances in analytical applications of immunoaffinity chromatography. J Chromatogr B Biomed Sci Appl Vol.715, No.1 (September 1998), pp. 3-28, ISSN 1387-2273.

Harlow, E. \& Lane, D. (1999a). Antibody Structure and Function. In: Using Antibodies, Harlow and Lane, pp. 1-20, Cold Spring Harbor laboratory Press, ISBN 978087969544-6, New York, USA.

Harlow, E. \& Lane, D. (1999b). Antibody-Antigen Interactions. In: Using Antibodies, Harlow and Lane, pp. 21-37, Cold Spring Harbor laboratory Press, ISBN 978-087969544-6, New York, USA.

Harlow, E. \& Lane, D. (1999c). Immunoaffinity Purification. In: Using Antibodies, Harlow and Lane, pp. 311-343, Cold Spring Harbor laboratory Press, ISBN 978-087969544-6, New York, USA.

Harrison, S.T. (1991). Bacterial cell disruption: a key unit operation in the recovery of intracellular products. Biotechnol Adv Vol.9, No.2, pp. 217-240, ISSN 0734-9750.

Hoogenboom, H.R. \& Chames, P. (2000). Natural and designer binding sites made by phage display technology. Immunol Today Vol. 21, No.8, (August 2000), pp. 371-378, ISSN 0167-5699.

Jensenius, J.C.; Andersen, I.; Hau, J.; Crone, M. \& Koch, C. (1981). Eggs: conveniently packaged antibodies. Methods for purification of yolk IgG. J Immunol Methods Vol.46, No.1, pp. 63-68, ISSN 0022-1759.

Kampf, C.; Andersson, A.C.; Wester, K.; Björling, E.; Uhlen, M. \& Ponten, F. (2004) Antibody-based tissue profiling as a tool for clinical proteomics. Clinical Proteomics Vol.1, No.3, (September 2004), pp. 285-299, ISSN 1542-6416.

Kim, H. \& Hage, D.S. (2006). Immobilization methods for affinity chromatography. In: Handbook of Affinity Chromatography, Hage, D.S. (Ed.). pp. 36-77, Taylor \& Francis, ISBN 978-0-8247-4057-3, New York, USA.

Koneracka, M.; Kopcansky, P.; Timbo, M.; Ramchand, C.N.; Saiyed, Z. M. \& Trevan, M. (2006). Immobilization of enzymes on magnetic particles. In: Immobilization of Enzymes and Cells, J.M. Guisan (Ed.), pp. 217-228, Humana Press, ISBN 978-1-58829290-2, New Jersey, USA.

Kortt, A.A.; Oddie, G.W.; Iliades, P.; Gruen, L.C. \& Hudson, P.J. (1997). Nonspecific amine immobilization of ligand can be a potential source of error in BIAcore binding 
experiments and may reduce binding affinities. Anal Biochem Vol.253, No.1 (November 1997), pp. 103-111, ISSN 0003-2697.

Kuby, J. (1992). Hybridomas and Monoclonal Antibody. In: Immunology, J. Kuby, pp. 141156, W.H. Freeman and Company, ISBN 0-7167-2257-7, New York, USA.

Larsson, K.; Wester K.; Nilsson, P.; Uhlen, M.; Hober, S. \& Wernerus, H. (2006). Multiplexed PrEST immunization for high-throughput affinity proteomics. J Immunol Methods Vol.315, No.1-2 (August 2006), pp. 110-120, ISSN 0022-1759.

Larsson, P.O. (1984). High-performance liquid affinity chromatography. Methods Enzymol Vol.104, pp. 212-223, ISSN 0076-6879.

Lesney, M. (2003). Sticking with affinity chromatography. Today's Chemist at Work, (August 2003), pp. 38-40, ISSN 1062-094X.

Libon, C.; Corvaia, N.; Haeuw, J.F.; Nguyen, T.N.; Stahl, S; Bonnefoy, J.Y. \& Andreoni, C. (1999). The serum albumin-binding region of streptococcal protein G (BB) potentiates the immunogenicity of the G130-230 RSV-A protein. Vaccine Vol.17, No.5, (February 1999), pp. 406-414, ISSN 0264-410X.

Lindskog, M.; Rockberg, J.; Uhlen, M. \& Sterky, F. (2005). Selection of protein epitopes for antibody production. Biotechniques Vol.38, No.5, pp. 723-727, ISSN 0736-6205 .

Little, M.; Kipriyanov, S. M.; Le Gall, F. \& Moldenhauer, G. (2000). Of mice and men: hybridoma and recombinant antibodies. Immunol Today Vol.21, No.8 (August 2000), pp. 364-370, ISSN 0167-5699.

Mallik, R.; Wa, C. \& Hage, D.S. (2007). Development of sulfhydryl-reactive silica for protein immobilization in high-performance affinity chromatography. Anal Chem Vol.79, No.4, (February 2007), pp. 1411-1424, ISSN 0003-2700.

Maynard, J. \& Georgiou, G. (2000). Antibody engineering. Annu Rev Biomed Eng Vol. 2, pp. 339-376, ISSN 1523-9829.

Michnick, S.W. \& Sidhu, S.S. (2008). Submitting antibodies to binding arbitration. Nat Chem Biol Vol.4, No.6 (June 2008), pp. 326-329, ISSN 1552-4469.

Moser, A. C. \& Hage, D.S. (2008). Capillary electrophoresis-based immunoassays: principles and quantitative applications. Electrophoresis Vol.29, No.16 (August 2008), pp. 32793295, ISSN 1557-7988.

Moser, A. C. \& Hage, D.S. (2010). Immunoaffinity chromatography: an introduction to applications and recent developments. Bioanalysis Vol.2, No.4 (April 2010), pp. 769790, ISSN 1757-6199.

Narhi, L.O.; Caughey, D.J.; Horan, T.; Kita, Y.; Chang, D. \& Arakawa, T. (1997). Effect of three elution buffers on the recovery and structure of monoclonal antibodies. Anal Biochem Vol.253, No.2, (November 1997), pp. 236-245, ISSN 0003-2697.

Nisnevitch, M. \& Firer, M.A. (2001). The solid phase in affinity chromatography: strategies for antibody attachment. J Biochem Biophys Methods Vol.49, No.1-3, pp. 467-480, ISSN 0165-022X.

O'Shannessy, D.J. \& Quarles, R.H. (1987). Labeling of the oligosaccharide moieties of immunoglobulins. J Immunol Methods Vol.99, No.2 (May 1987), pp. 153-161, ISSN 0022-1759.

Phillips, T.M. \& Wellner, E.F. (2007). Analysis of inflammatory biomarkers from tissue biopsies by chip-based immunoaffinity CE. Electrophoresis Vol.28, No.17 (August 2007), pp. 3041-3048, ISSN 0173-0835. 
Pini, A. \& Bracci, L. (2000). Phage display of antibody fragments. Curr Protein Pept Sci Vol. 1, No.2, (September 2000), pp. 155-169, ISSN 1389-2037.

Rader, C. \& Barbas, C.F. $3^{\text {rd }}$ (1997). Phage display of combinatorial antibody libraries. Curr Opin Biotechnol Vol.8, No.4 (August 1997), pp. 503-508, ISSN 0958-1669.

Ruhn, P.F.; Graver, S. \& Hage, D.S. (1994). Development of dihydrazide-activated silica supports for high-performance affinity chromatography. J Chromatogr A Vol.669, No.1-2, (May 1994), pp. 9-19, ISSN 0021-9673.

Schneider, C.; Newman, R.A.; Sutherland, D.R.; Asser, U. \& Greaves, M.F. (1982). A one-step purification of membrane proteins using a high efficiency immunomatrix. J Biol Chem Vol.257, No.18, (September 1982), pp. 10766-10769, ISSN 0021-9258.

Schuste, M.; Wasserbauer, E.; Neubauer, A. \& Jungbauer, A. (2000). High speed immunoaffinity chromatography on supports with gigapores and porous glass. Bioseparation Vol.9, No.5, pp. 259-268, ISSN 0923-179X.

Şenyuva, H.Z. \& Gilbert, J. (2010). Immunoaffinity column clean-up techniques in food analysis: A review. J Chromatogr B Analyt Technol Biomed Life Sci Vol.878, No.2 (January 2010), pp. 115-132, ISSN 1873-376X.

Singh, K.V.; Kaur, J.; Raje, M.; Varshney, G.C. \& Suri, C.R. (2003). An ELISA-based approach to optimize elution conditions for obtaining hapten-specific antibodies. Anal Bioanal Chem Vol.377, No.1, (September 2003), pp. 220-224, ISSN 1618-2642.

Smith, G.P. \& Petrenko, V.A. (1997). Phage Display. Chem Rev Vol. 97, No.2, (April 1997), pp. 391-410, ISSN 1520-6890.

Spitznagel, T.M.; Jacobs, J.W. \& Clark, D.S. (1993). Random and site-specific immobilization of catalytic antibodies. Enzyme Microb Technol Vol.15, No.11, (November 1993), pp. 916-921, ISSN 0141-0229.

Turková, J. (1999). Oriented immobilization of biologically active proteins as a tool for revealing protein interactions and function. J Chromatogr B Biomed Sci Appl Vol.722, No.1-2, (February 1999), pp. 11-31. ISSN 1387-2273.

Urh, M.; Simpson, D. \& Zhao, K. (2009). Affinity chromatography: general methods. Methods Enzymol Vol.463, pp. 417-438, ISSN 1557-7988.

Weller, M. G. (2000). Immunochromatographic techniques--a critical review. Fresenius J Anal Chem Vol.366, No.6-7 (March-April 2000), pp. 635-645, ISSN 0937-0633

Winter, G. \& C. Milstein (1991). Man-made antibodies. Nature Vol.349, No.6307 (January 1991), pp. 293-299, ISSN 0028-0836.

Yokota, T.; Milenic, D.E.; Whitlow, M. \& Schlom, J. (1992). Rapid tumor penetration of a single-chain Fv and comparison with other immunoglobulin forms. Cancer Res Vol. 52, No.12 (June 1992), pp. 3402-3408, ISSN 0008-5472. 


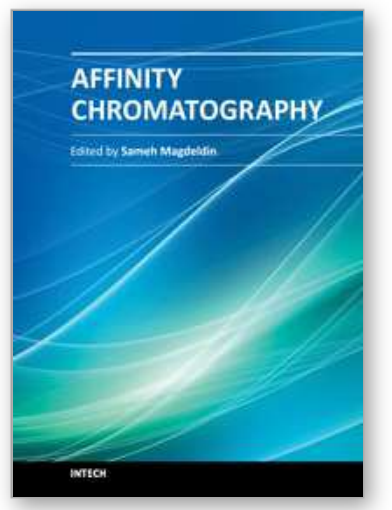

\author{
Affinity Chromatography \\ Edited by Dr. Sameh Magdeldin
}

ISBN 978-953-51-0325-7

Hard cover, 368 pages

Publisher InTech

Published online 21, March, 2012

Published in print edition March, 2012

Most will agree that one major achievement in the bio-separation techniques is affinity chromatography. This coined terminology covers a myriad of separation approaches that relies mainly on reversible adsorption of biomolecules through biospecific interactions on the ligand. Within this book, the authors tried to deliver for you simplified fundamentals of affinity chromatography together with exemplarily applications of this versatile technique. We have always been endeavor to keep the contents of the book crisp and easily comprehensive, hoping that this book will receive an overwhelming interest, deliver benefits and valuable information to the readers.

\title{
How to reference
}

In order to correctly reference this scholarly work, feel free to copy and paste the following:

Daad A. Abi-Ghanem and Luc R. Berghman (2012). Immunoaffinity Chromatography: A Review, Affinity Chromatography, Dr. Sameh Magdeldin (Ed.), ISBN: 978-953-51-0325-7, InTech, Available from: http://www.intechopen.com/books/affinity-chromatography/immunoaffinity-chromatography-a-review

\section{INTECH}

open science | open minds

\section{InTech Europe}

University Campus STeP Ri

Slavka Krautzeka 83/A

51000 Rijeka, Croatia

Phone: +385 (51) 770447

Fax: +385 (51) 686166

www.intechopen.com

\section{InTech China}

Unit 405, Office Block, Hotel Equatorial Shanghai

No.65, Yan An Road (West), Shanghai, 200040, China

中国上海市延安西路 65 号上海国际贵都大饭店办公楼 405 单元

Phone: +86-21-62489820

Fax: +86-21-62489821 
(C) 2012 The Author(s). Licensee IntechOpen. This is an open access article distributed under the terms of the Creative Commons Attribution 3.0 License, which permits unrestricted use, distribution, and reproduction in any medium, provided the original work is properly cited. 